\title{
Beavers indicate metal pollution away from industrial centers in northeastern Poland
}

\author{
Aleksandra Giżejewska • Anna Spodniewska • Dariusz Barski • \\ Julien Fattebert
}

Received: 6 August 2014 / Accepted: 23 October 2014 / Published online: 5 November 2014

(C) The Author(s) 2014. This article is published with open access at Springerlink.com

\begin{abstract}
Heavy metals are persistent environmental contaminants, and wild animals are increasingly exposed to the harmful effects of compounds of anthropogenic origin, even in areas distant from industrial centers. We used atomic absorption spectrometry to determine levels of cadmium $(\mathrm{Cd})$, lead $(\mathrm{Pb})$, copper $(\mathrm{Cu})$, and zinc $(\mathrm{Zn})$ in liver and kidney of wild Eurasian beavers (Castor fiber) in Poland. Cd concentrations in liver $(0.21 \pm 0.44 \mu \mathrm{g} / \mathrm{g})$ and in kidney $(2.81 \pm$ $4.52 \mu \mathrm{g} / \mathrm{g}$ ) were lower in juvenile than in adult beavers. $\mathrm{Pb}$ concentrations in liver $(0.08 \pm 0.03 \mu \mathrm{g} / \mathrm{g})$ and kidney $(0.08 \pm$ $0.03 \mu \mathrm{g} / \mathrm{g}$ ) were similar among all individuals, while both $\mathrm{Cu}$ and $\mathrm{Zn}$ levels were higher in liver $(\mathrm{Cu} 9.2 \pm 4.5 \mu \mathrm{g} / \mathrm{g}$; $\mathrm{Zn} 35.7$ $\pm 3.5 \mu \mathrm{g} / \mathrm{g}$ ) than in kidney (Cu $3.7 \pm 1.1 \mu \mathrm{g} / \mathrm{g} ; \mathrm{Zn} 21.5 \pm 2.7 \mu \mathrm{g} /$ g). $\mathrm{Cu}$ levels also differed between juveniles and adults. We reviewed the literature reporting metal concentrations in beavers. Our results indicate metal contamination in beavers away from important industrial emission sources and suggest the natural environment should be regularly monitored to ensure their levels are below recommended, legal values.
\end{abstract}

Keywords Castor fiber - Contamination · Cadmium . Copper $\cdot$ Lead $\cdot$ Zinc $\cdot$ Liver $\cdot$ Kidney

Responsible editor: Stuart Simpson

A. Giżejewska $(\triangle) \cdot$ A. Spodniewska $\cdot$ D. Barski

Department of Pharmacology and Toxicology, Faculty of Veterinary

Medicine, University of Warmia and Mazury in Olsztyn,

10-957 Olsztyn, Poland

e-mail: aleksandra.gizejewska@uwm.edu.pl

J. Fattebert

School of Life Sciences, University of KwaZulu-Natal, Westville

Campus, Durban 4000, South Africa

\section{Introduction}

Wild animals are exposed to environmental contaminants of both natural and anthropogenic origin and are suitable bioindicators of environmental pollution (O'Brien et al. 1993; Mason and Stephenson 2001; Ansara-Ross et al. 2013; Petkovšek et al. 2014). Concentrations of toxic compounds in body tissues are determined by the degree of exposure, the compound's bioavailability and half-life, as well as the type of tissue (Nordberg et al. 2011a). Pollutants can be transported over significant distances by air or water, and they are found even in regions situated remotely from industrial centers (Ansara-Ross et al. 2013; Jerez et al. 2013). Therefore, due to the rapid development and wide diversity of human activities, animals are increasingly exposed to harmful effects of compounds of anthropogenic origin (O'Brien et al. 1993). With growing public awareness of environmental pollution, regular monitoring of pollutants in the environment is essential to ensure levels of pollutants are below harmful or recommended, legal values (Nasreddine and Parent-massin 2002; European Commission 2006). Such monitoring should be carried out not only in industrialized areas but also in natural and agricultural ecosystems away from the source of emissions (Nasreddine and Parent-massin 2002; Szkoda et al. 2012).

Metals include toxic elements such as cadmium (Cd) and lead $(\mathrm{Pb})$, as well as essential elements in which toxicity is determined by the dose, as copper $(\mathrm{Cu})$ and zinc $(\mathrm{Zn})$. Although these four elements occur naturally in the environment, they are supplied in large quantities through domestic and industrial pollution (Bjerregaard and Andersen 2011). Heavy metals are also persistent environmental contaminants whose physiochemical properties contribute to their mobility in the natural environment, posing a significant threat for living organisms and ecosystems (Bjerregaard and Andersen 2011). 
Previous studies reported essential and toxic metals in beaver (family: Castoridae) tissues obtained from industrial areas, generally regarded as polluted (Hillis and Parker 1993; Zalewski et al. 2012), agricultural regions (Fimreite et al. 2001), and natural ecosystems (Wren 1984; Zalewski et al. 2012; Giżejewska et al. 2014). Beavers are semi-aquatic, territorial herbivorous rodents feeding on the bark, shoots, and leaves of a wide variety of woody plants including willow (Salix sp.) and aspen (Populus tremuloides), as well as on nonwoody terrestrial and aquatic plants (Haarberg and Rosell 2006; Krojerová-Prokešová et al. 2010). Beavers' catholic diet and sedentary behavior make them suitable bioindicators of local environmental pollution. In Poland, the status of Eurasian beavers (Castor fiber) as a "partially protected" species (Polish Minister of the Environment 2011) contributed to rapid population growth. It is currently estimated that 78,000 beavers occur in the country, and beaver populations continue spreading to new areas, including near human settlements, where they are likely to get exposed to anthropogenic pollutants (Flis 2013).

In this study, our aim was to use the Eurasian beaver as a bioindicator organism (i) to assess trace element contents in a region away from major industrial centers and (ii) to evaluate the degree of contamination against legal $\mathrm{Cd}$ and $\mathrm{Pb}$ levels recommended by the European Commission in farm animal edible tissues (European Commission 2006) with regard to the lack of an official threshold for wildlife (Giżejewska et al. 2014). Specifically, we measured concentrations of $\mathrm{Cd}, \mathrm{Pb}$, $\mathrm{Cu}$, and $\mathrm{Zn}$ in liver and kidney of wild beavers. We predicted (i) metal concentrations to differ between liver and kidney according to element-specific metabolism, (ii) no sexual difference in metal concentrations in this non-dimorphic species, and (iii) higher metal concentrations in adult than in juvenile individuals because of bioaccumulation processes. We also present a review of the literature reporting metal concentration in beavers. We compared our results with previous research, and we discuss the implications for future use of beavers as bioindicators for the monitoring of metal pollution.

\section{Material and methods}

Eurasian beavers were captured in Wiżajny municipality $\left(22^{\circ}\right.$ $52^{\prime} \mathrm{E} ; 54^{\circ} 22^{\prime} \mathrm{N}$ ), Warmia and Mazury Region, northeastern Poland, in Summer 2012. Warmia and Mazury is a traditional agricultural region with extensive forests and numerous lakes. The region is an important recreational center for local and international tourists who seek activities in a natural environment. The sampling site was away from a major industrial complex, which could putatively be a source of pollutants in their vicinity. Animals were collected upon approval of the Regional Nature Conservation Authority (Opinion No.
RDOŚ-28-OOP-6631-0007-638/09/10/pj 2010) and the Local Ethics Committee (Opinion No. 11/2010).

All beavers were collected during daytime with a net and transported to the laboratory in cages specially adapted for this purpose (Zalewski et al. 2012; Giżejewska et al. 2014). All animals were healthy and in good physical condition at the time of capture. Their age was estimated based on body weight (Rosell et al. 2010), and they were classified into two age classes: (i) juveniles, 2 months old, and (ii) adults, $>24$ months old (Table 1). Sex was determined based on the color of anal gland secretions (Schulte et al. 1995). Beavers were anesthetized with xylazine and ketamine in doses appropriate to body weight, and body measurements taken.

Then, beavers were sacrificed by decapitation under full anesthesia. Liver and kidney samples of c. $15 \mathrm{~g}$ each were collected and stored in polyethylene bags at $-25{ }^{\circ} \mathrm{C}$ until analysis (Zalewski et al. 2012; Giżejewska et al. 2014). Each sample was homogenized and two subsamples were prepared from each individual organ and analyzed twice each as replicates. All tissue samples were mineralized in the muffle furnace at $450{ }^{\circ} \mathrm{C}$ for $24 \mathrm{~h}$. Ashes were dissolved in $1 \mathrm{M} \mathrm{HNO}_{3}$ and deionized water was added to $25 \mathrm{ml}$ (Euczyńska et al. 2009). We performed graphite furnace atomic absorption spectroscopy to determine $\mathrm{Cd}$ and $\mathrm{Pb}$ concentrations and flame atomic absorption spectroscopy to determine $\mathrm{Cu}$ and $\mathrm{Zn}$ concentrations (Whiteside and Milner 1984) using an iCE 3000 Series spectrometer (Thermo Scientific, UK).

Analysis for each element was performed based on calibration curves plotted from working standards. For calibration, we used commercial stock solutions $(1000 \mathrm{mg} / \mathrm{l})$ of analytical grade for all four elements (J.T.Baker $\left.{ }^{\circledR}\right)$. Working standards were prepared by dissolving stock solutions with $0.1 \mathrm{M} \mathrm{HNO}_{3}$ and deionized water. Calibration ranges were $0.0005-0.004 \mu \mathrm{g} / \mathrm{g}$ for $\mathrm{Cd}, 0.001-0.01 \mu \mathrm{g} / \mathrm{g}$ for $\mathrm{Pb}, 0.05$ $0.8 \mu \mathrm{g} / \mathrm{g}$ for $\mathrm{Cu}$, and $0.1-0.8 \mu \mathrm{g} / \mathrm{g}$ for $\mathrm{Zn}$, respectively. Limits of detection were $0.002 \mu \mathrm{g} / \mathrm{g}$ for $\mathrm{Cd}, 0.001 \mu \mathrm{g} / \mathrm{g}$ for $\mathrm{Pb}$, and $0.05 \mu \mathrm{g} / \mathrm{g}$ for $\mathrm{Cu}$ and $\mathrm{Zn}$. Reagent blanks and control samples

Table 1 Biometric data of 10 Eurasian beavers from Wiżajny municipality, northeastern Poland, 2012

\begin{tabular}{|c|c|c|c|c|}
\hline Individual & Sex & Age class & Body weight (kg) & Body length $(\mathrm{cm})$ \\
\hline M1 & $\hat{\sigma}$ & Juvenile & 2.5 & 62 \\
\hline M2 & $\hat{\sigma}$ & Juvenile & 2.8 & 62 \\
\hline F3 & 우 & Juvenile & 2.8 & 64 \\
\hline $\mathrm{F} 4$ & 우 & Juvenile & 2.7 & 60 \\
\hline M5 & $\hat{\sigma}$ & Adult & 18.6 & 116 \\
\hline M6 & $\hat{0}$ & Adult & 22.6 & 114 \\
\hline F7 & q & Adult & 17.3 & 115 \\
\hline F8 & q & Adult & 21.1 & 117 \\
\hline F9 & q & Adult & 22.7 & 118 \\
\hline F10 & q & Adult & 22.0 & 121 \\
\hline
\end{tabular}


Table 2 Summary statistics of the concentration ( $\mu \mathrm{g} / \mathrm{g}$ wet weight) of four metals $(\mathrm{Cd}, \mathrm{Pb}, \mathrm{Cu}$, and $\mathrm{Zn})$ in liver and kidney of 10 Eurasian beavers, NE Poland, 2012

\begin{tabular}{cccll}
\hline Metal & Mean \pm SD & Median & Range & $\begin{array}{l}\text { Maximum } \\
\text { legal level }\end{array}$ \\
\hline Liver & & & & \\
$\mathrm{Cd}$ & $0.21 \pm 0.44$ & 0.06 & $0.03-1.44$ & 0.5 \\
$\mathrm{~Pb}$ & $0.08 \pm 0.03$ & 0.06 & $0.05-0.12$ & 0.5 \\
$\mathrm{Cu}$ & $9.2 \pm 4.5$ & 6.9 & $5.2-16.4$ & $-^{\mathrm{b}}$ \\
$\mathrm{Zn}$ & $35.7 \pm 3.5$ & 36.2 & $31.4-40.6$ & $-^{\mathrm{b}}$ \\
$\mathrm{Kidney}$ & & & & \\
$\mathrm{Cd}$ & $2.81 \pm 4.52$ & 1.37 & $0.02-14.88$ & 1.0 \\
$\mathrm{~Pb}$ & $0.08 \pm 0.03$ & 0.07 & $0.05-0.14$ & 0.5 \\
$\mathrm{Cu}$ & $3.7 \pm 1.1$ & 3.5 & $3.0-3.8$ & $-{ }^{\mathrm{b}}$ \\
$\mathrm{Zn}$ & $21.5 \pm 2.7$ & 20.2 & $19.0-27.9$ & ${ }^{\mathrm{b}}$ \\
\hline
\end{tabular}

${ }^{a}$ Maximum levels set by the European Commission (2006) for contaminants of toxic elements in food of animal origin

${ }^{\mathrm{b}}$ No regulation

containing all reagents were prepared and run in duplicate. Quality control of analytical measurements was performed using certified reference material (BCR-185R bovine liver, IRRM, Belgium). Each working solution was analyzed in duplicate and calibration curves were periodically verified. Recoveries of all four elements were within the range 86$109 \%$ and relative standard deviations were below $10 \%$.

Metal concentrations were expressed in micrograms per gram of wet weight, with precision consistent with limits of quantitation $-0.001 \mu \mathrm{g} / \mathrm{g}$ for $\mathrm{Cd}$ and $\mathrm{Pb}$ and $0.1 \mu \mathrm{g} / \mathrm{g}$ for $\mathrm{Cu}$ and $\mathrm{Zn}$. Metal concentrations were contrasted between organs among all beavers using a paired $t$ test. Concentrations in beaver livers and kidneys were compared between age or sex classes using a non-parametric Mann-Whitney $U$ test. Pair-wise comparisons between element concentrations in each organ were performed using a Spearman rank correlation analysis. We report arithmetic means, standard deviations (SD), median, and range. Where necessary, data were transformed to meet statistical assumptions. Significance level was set at $p<0.05$, and all statistical analyses were run using $\mathrm{R}$ version 3.0.0 (R Core Team 2013).

\section{Results}

We captured six female (four adults, two juveniles) and four male (two adults, two juveniles) beavers (Table 1). Mean concentrations of $\mathrm{Cd}, \mathrm{Pb}, \mathrm{Cu}$, and $\mathrm{Zn}$ determined in liver and kidney samples are presented in Table 2 and compared with the literature (Table 3). Higher concentrations in liver than in kidney were found for $\mathrm{Cu}(t=-4.534 ; d f=9 ; p=0.001)$ and $\mathrm{Zn}(t=-19.826 ; d f=9 ; p<0.001)$. Additionally, Zn levels were significantly correlated to $\mathrm{Cd}$ levels in kidney $(n=10$, $\left.r_{s}=0.939 ; p<0.001\right)$.

We found no differences between female $(n=6)$ and male $(n=4)$ beavers for any of the four metal concentrations in liver or kidney (Fig. 1). Contrastingly, we found significant differences in $\mathrm{Cd}$ and $\mathrm{Cu}$ concentrations between adult and juvenile beavers (Fig. 2). Cadmium concentrations were significantly higher in adults $(n=6)$ than in juveniles $(n=4)$ in both liver $(U=0.0 ; Z=-2.452 ; p=0.014)$ and kidney $(U=0.0 ; Z=$ $-2.452 ; p=0.014)$. In liver, $\mathrm{Cu}$ levels were significantly lower in adults than in juveniles $(U=0.0 ; Z=2.452 ; p=0.014)$, and in kidney, $\mathrm{Cu}$ levels were significantly higher in adults than in juveniles $(U=2.0 ; Z=-2.025 ; p=0.043)$.

\section{Discussion}

Our study revealed the presence of $\mathrm{Cd}, \mathrm{Pb}, \mathrm{Cu}$, and $\mathrm{Zn}$ in liver and kidney of all sampled beavers. No relationship was observed between metal concentrations and the

Table 3 Average concentrations ( $\mu \mathrm{g} / \mathrm{g}$ wet weight) of $\mathrm{Cd}, \mathrm{Pb}, \mathrm{Zn}$, and $\mathrm{Cu}$ in liver and kidney of beavers (family: Castoridae) given in the literature

\begin{tabular}{|c|c|c|c|c|c|c|c|c|c|c|}
\hline \multirow[t]{2}{*}{ Species } & \multicolumn{4}{|l|}{ Liver } & \multicolumn{4}{|c|}{ Kidney } & \multirow[t]{2}{*}{ Sites } & \multirow[t]{2}{*}{ Reference } \\
\hline & $\mathrm{Cd}$ & $\mathrm{Pb}$ & $\mathrm{Cu}$ & $\mathrm{Zn}$ & $\mathrm{Cd}$ & $\mathrm{Pb}$ & $\mathrm{Cu}$ & $\mathrm{Zn}$ & & \\
\hline C. fiber & 0.21 & 0.08 & 9.2 & 35.7 & 2.81 & 0.08 & 3.7 & 21.5 & Unpolluted & This study \\
\hline C. fiber & 0.88 & 0.11 & - & - & 7.93 & 0.06 & - & - & Unpolluted & Giżejewska et al. (2014) \\
\hline C. fiber & 0.58 & 0.19 & 4.04 & 23.73 & 7.10 & 0.13 & 2.73 & 25.23 & Former military airport & Zalewski et al. (2012) \\
\hline C. fiber & 0.22 & 0.14 & 4.40 & 27.52 & 2.44 & 0.09 & 3.15 & 27.05 & Unpolluted & Zalewski et al. (2012) \\
\hline C. fiber & 1.03 & - & 2.8 & 27.66 & 10.25 & - & 2.17 & 23.11 & Unpolluted & Fimreite et al. (2001) \\
\hline C. canadensis & 2.3 & 2.7 & 8 & 80.8 & 18.8 & 3.4 & 9.3 & 99.3 & $15 \mathrm{~km}$ from ore smelter & Hillis and Parker (1993) \\
\hline C. canadensis & - & 1.4 & - & - & - & 2.1 & - & - & $90 \mathrm{~km}$ from ore smelter & Hillis and Parker (1993) \\
\hline C. canadensis & 0.19 & - & 2.9 & 29.6 & 1.44 & - & 3 & 25.4 & $175 \mathrm{~km}$ from ore smelter & Wren (1984) \\
\hline
\end{tabular}


Fig. 1 Concentrations $(\mu \mathrm{g} / \mathrm{g}$ wet weight) of $\mathrm{Cd}, \mathrm{Pb}, \mathrm{Cu}$, and $\mathrm{Zn}$ in a liver and $\mathbf{b}$ kidney of six female and four male Eurasian beavers, NE Poland, 2012. No statistical significant difference in metal concentrations between sex classes was found (MannWhitney $U$ test, all $p>0.5$ ). Box and whisker plots show median (horizontal line within box), 25 and $75 \%$ percentiles (box), 1.5 interquartile range (whiskers). For clarity, extreme outliers are not shown
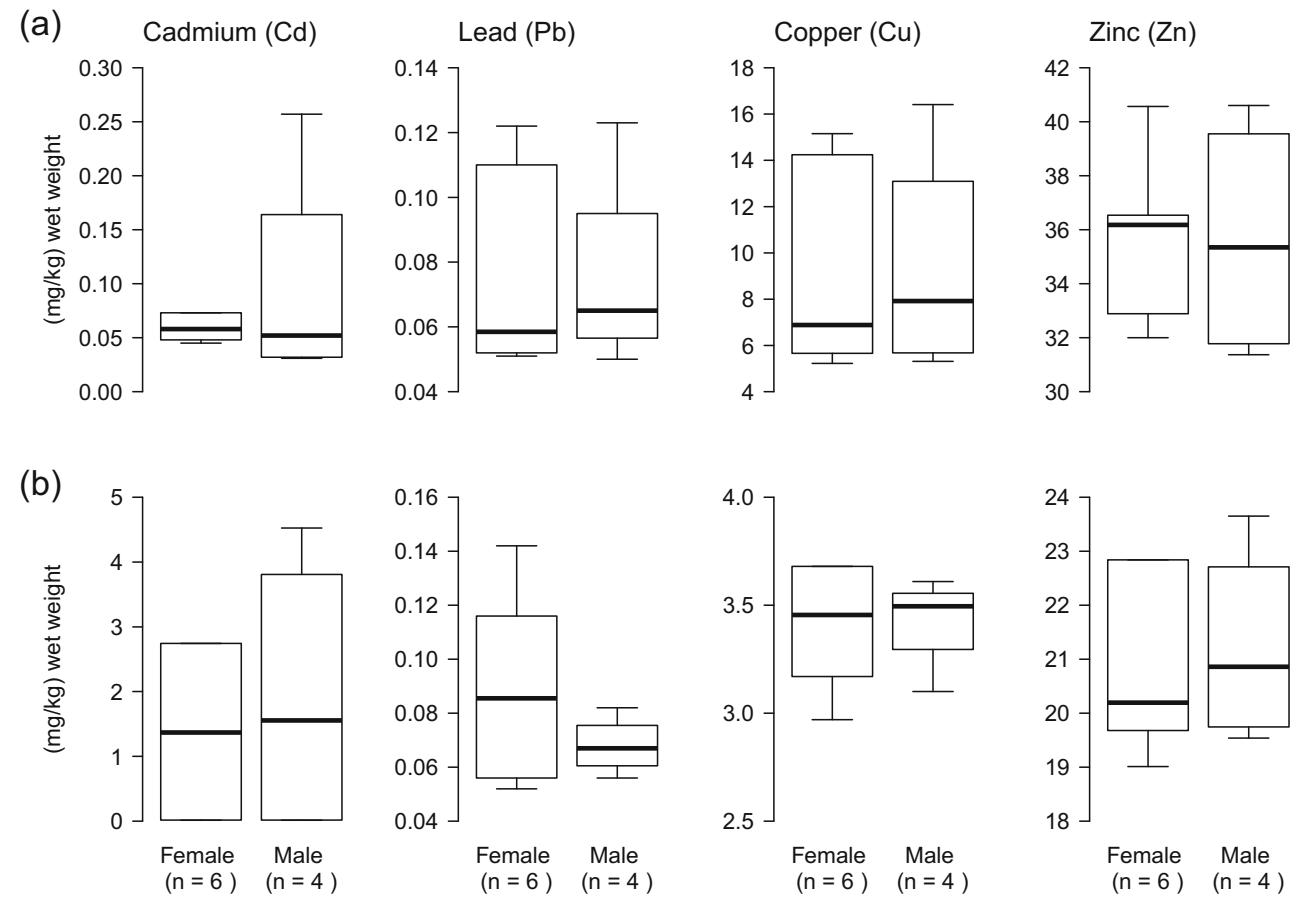

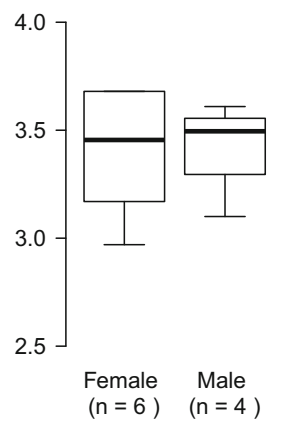

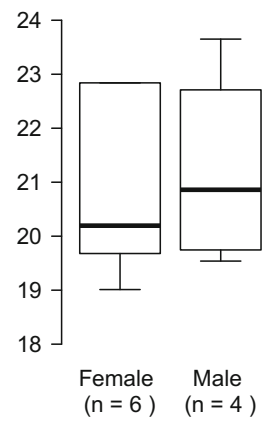

beavers' sex. Although we acknowledge the limitations of the tests due to a reduced number of individuals in each group, these results were expected as the species present no sexual dimorphism and no partitioning in diet (Haarberg and Rosell 2006; Krojerová-Prokešová et al. 2010). Therefore, it was expected that both sexes be exposed similarly to environmental pollution.
Contrastingly, some metal concentrations were affected by the animals' age. Higher liver and kidney $\mathrm{Cd}$ concentrations were found in adult beavers than in juveniles, indicating that this metal bioaccumulates over time (Parker and Hamr 2001; Bilandžić et al. 2010; Giżejewska et al. 2014). Cd levels in all six adult beavers exceed the maximum threshold of $1.0 \mu \mathrm{g} / \mathrm{g}$ in kidney recommended in farm animal edible tissues. In liver,
Fig. 2 Concentrations $(\mu \mathrm{g} / \mathrm{g}$ wet weight) of $\mathrm{Cd}, \mathrm{Pb}, \mathrm{Cu}$, and $\mathrm{Zn}$ in a liver and $\mathbf{b}$ kidney of six adult and four juvenile Eurasian beavers, NE Poland, 2012. Significant statistical differences in metal concentrations between age classes were found in liver $\mathrm{Cd}$ $(U=0.0 ; Z=-2.452 ; p=0.014)$ and $\mathrm{Cu}(U=0.0 ; Z=2.452 ; p=$ $0.014)$ and in kidney $\mathrm{Cd}(U=0.0$; $Z=-2.452 ; p=0.014)$ and $\mathrm{Cu}(U=$ $2.0 ; Z=-2.025 ; p=0.043)$. Box and whisker plots show median (horizontal line within box), 25 and $75 \%$ percentiles (box), 1.5 interquartile range (whiskers), and statistical outliers (open circles). For clarity, extreme outliers are not shown
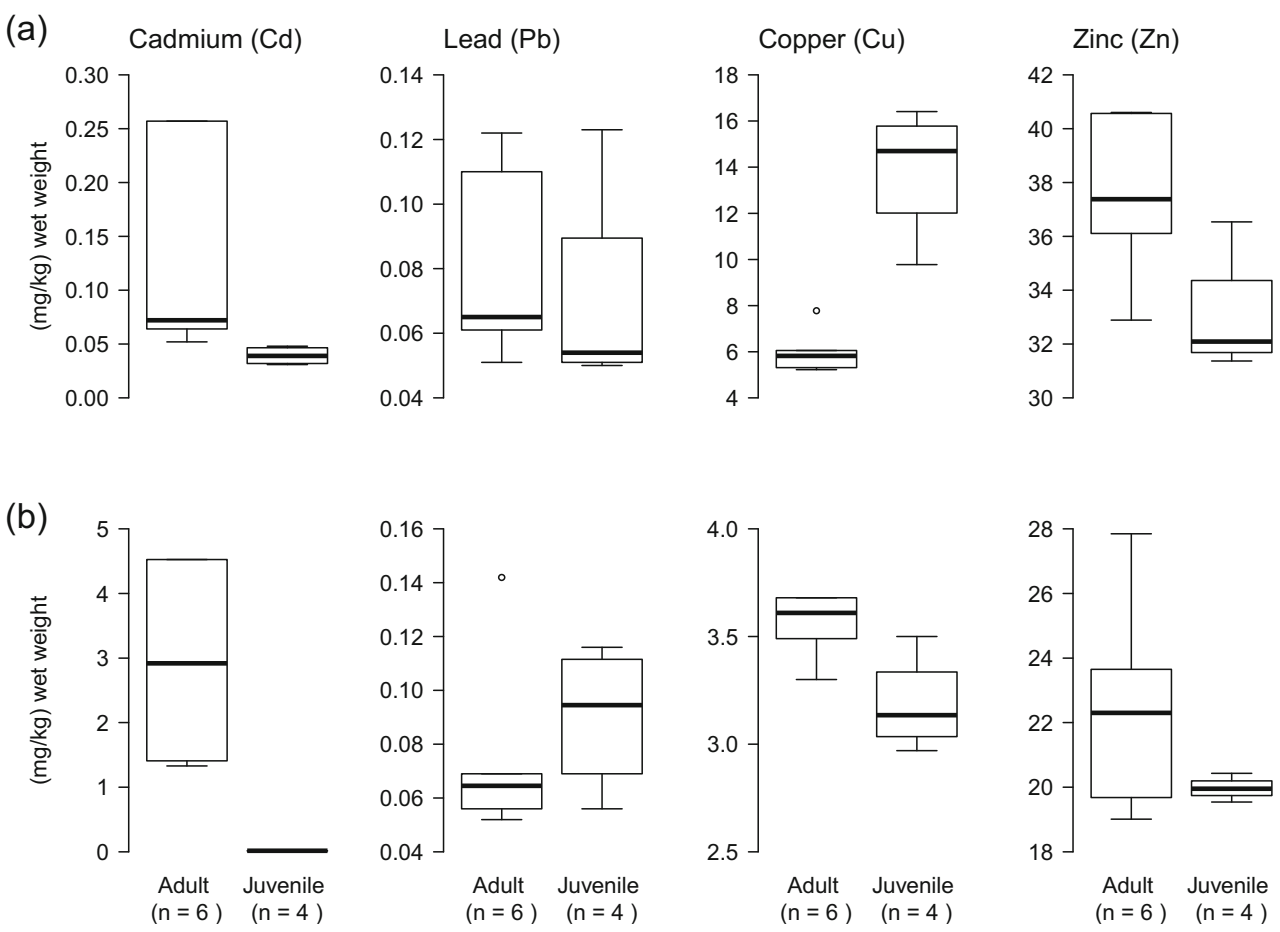
however, only one adult female (F7) exceeded the recommended $0.5 \mu \mathrm{g} / \mathrm{kg} \mathrm{Cd}$ limit (European Commission 2006). Such differences in Cd levels with age might be due to this metal accumulating over an animal's entire life span, especially in kidney, as previously described in other species (e.g., red fox (Vulpes vulpes) and stone marten (Martes foina): Bilandžić et al. 2010; African grass owl (Tyto capensis): Ansara-Ross et al. 2013; penguins (Pygoscelis spp.): Jerez et al. 2013).

Average $\mathrm{Cd}$ content in kidney was similar to that observed in 2003 in beavers from Srokowo Forest Division, an uncontaminated area in northeastern Poland (Zalewski et al. 2012). However, our results were approximately four- to fivefold lower in liver and three- to fourfold lower in kidney than levels measured in earlier studies on beaver at unpolluted sites in Poland (Giżejewska et al. 2014), in Norway (Fimreite et al. 2001), and in a putatively contaminated former air base in Poland (Zalewski et al. 2012). Contrastingly, Cd concentrations in liver and kidney were higher than those reported in Canadian beavers (Castor canadensis) in habitats located $175 \mathrm{~km}$ from an ore smelter in Ontario, Canada (Wren 1984).

Cadmium concentration in wildlife tissue is attributed to its levels in the environment and additionally with animals' age. Previous studies concerned with $\mathrm{Cd}$ content in unpolluted areas presented values that could be attributed to metal transport over long distances from the pollution source as well as increased mobility due to soil and water acidification (Wren 1984). Metal concentrations in animals' tissues can be attributed to diet (Fimreite et al. 2001; Brekken and Steinnes 2004; Zalewski et al. 2012). Although metal concentrations in food sources typically consumed by beavers were not examined in the present study, it has been reported that beavers have a strong preference for aspen (P. tremuloides) and willow (Salix sp.), trees that accumulate high levels of Cd particularly on acidic soils that increase the mobility of heavy metals (Wren 1984). Cd is easily absorbed and accumulates even at low levels of chronic exposure (Nordberg et al. 2011b). Interspecific differences, intraspecific variations among populations, or physiological determinants of metal absorption and excretion can also contribute to the observed differences (Nordberg et al. 2011a).

All values of $\mathrm{Pb}$ found in beavers were below the $0.5 \mu \mathrm{g} / \mathrm{g}$ threshold recommended for both organs in farm animal edible tissues (European Commission 2006). Lead concentrations in kidney ranged from $0.052 \mu \mathrm{g} / \mathrm{g}$ (F9) to $0.142 \mu \mathrm{g} / \mathrm{g}$ (F10). Lead passes the placenta and young animals have a higher rate of absorption from the intestinal tract (Nordberg et al. 2011a). As this metal is not metabolically regulated in organisms, $\mathrm{Pb}$ concentrations in animal tissues are related to its presence in the ecosystem (Jerez et al. 2013). Soil intentionally or accidentally consumed by beavers could constitute an additional source of contamination as $\mathrm{Pb}$ can be bound in soil and bottom sediments and secondarily released (Rajaganapathy et al. 2011). Lead concentrations in our study were low compared to previous research (Table 3). This could be attributed to the absence of major industrial sites close to the sample site, seasonality, or individual variability in diet (Brekken and Steinnes 2004). Regardless, $\mathrm{Pb}$ threat to beavers appears low in the region.

We found significantly higher levels of $\mathrm{Cu}$ and $\mathrm{Zn}$ in liver than in kidney. Copper absorption is regulated by homeostatic mechanisms in the liver and is mainly excreted through the bile. Absorbed $\mathrm{Zn}$ is bound to plasma albumin and macroglobulins and distributed to the liver where it rapidly accumulates (Parker and Hamr 2001). Although $\mathrm{Cu}$ has higher affinity than $\mathrm{Zn}$ to metallothionein (low molecular weight metal-binding protein) which binds $\mathrm{Cu}$ and $\mathrm{Zn}$ at low levels of $\mathrm{Cd}$ (Hillis and Parker 1993; Nordberg et al. 2011a), hepatic metallothionein seems to have an important role in accumulation and storage of both $\mathrm{Cu}$ and $\mathrm{Zn}$ in the liver (Parker and Hamr 2001). Copper concentrations were higher in juvenile than in adult beavers in liver, indicating age-specific metabolism capabilities of this microelement (Nordberg et al. 2011a). Higher $\mathrm{Cu}$ levels in juveniles' liver can be attributed to increased requirements for this element in growing organisms (Parker and Hamr 2001; Jerez et al. 2013). Our $\mathrm{Cu}$ values in both liver and kidney were higher than those in previous studies (Table 3). Copper as an essential microelement has effective regulation mechanisms of uptake and excretion, and beaver diet contains high amounts of $\mathrm{Cu}$ and $\mathrm{Zn}$ (Brekken and Steinnes 2004). Therefore, we assume that our values were at normal physiological levels (Nordberg et al. 2011a).

Zinc concentrations did not differ between organs and sex or age classes in our study. However, excluding beavers collected in the vicinity of the ore smelter in Ontario, Canada, where $\mathrm{Zn}$ concentrations reached $80.8 \mu \mathrm{g} / \mathrm{g}$ in the liver (Hillis and Parker 1993), we found $\mathrm{Zn}$ levels in liver higher than in previous studies (Table 3). In kidney, Zn levels were highly correlated to $\mathrm{Cd}$ levels regardless of the beaver age or sex. Zinc and cadmium have similar chemical properties, and they are usually found as a mineral combination in the environment (Nordberg et al. 2011b). Metallothionein can bind $\mathrm{Cd}, \mathrm{Cu}$, and $\mathrm{Zn}$, and this protein will bind most of the $\mathrm{Cd}$ and store it in kidney. Exposure to low Cd levels may cause a redistribution of $\mathrm{Zn}$ in the organism, increasing $\mathrm{Zn}$ concentrations in kidney (Nordberg et al. 2011a). Higher kidney Zn concentrations were reported in beavers from Ontario (Hillis and Parker 1993). The highest $\mathrm{Zn}$ concentrations (liver $40.6 \mu \mathrm{g} / \mathrm{g}$; kidney $27.9 \mu \mathrm{g} / \mathrm{g}$ ) we found in adult female F7 could also possibly be attributed to a diet rich in this microelement (Brekken and Steinnes 2004). 


\section{Conclusion and outlook}

General metal concentrations in beaver tissues from northeastern Poland were similar to or lower than those found in other countries. This was expected as our study area was away from major industrial centers. However, the fact that high Cd concentrations and $\mathrm{Pb}$ were present in a putatively unpolluted area calls for a regular monitoring of environmental pollutants in agricultural and natural areas. Future investigation of trace elements in beaver tissues sampled from industrial regions is needed for comparison and to draw further conclusion about levels of contamination. Significant expansion of beaver populations in Poland contributes to growing human-beaver conflict, increasing the amount of compensation paid to farmers and landowners. Although beaver is currently not considered as a consumptive species in Poland, beaver is classified as a game species in six European countries (Belarus, Estonia, Lithuania, Latvia, Norway, and Sweden) as well as in Canada and Russia (Jankowska et al. 2005). Hunting beavers for consumption has been suggested as a tool for population management, and beaver consumption could occur in the near future in Poland. Research to ascertain tissues are safe from a toxicological point of view is therefore timely. In this context, the fact that $\mathrm{Cd}$ concentrations in adult beavers exceeded limits recommended in farm animal tissues warrants caution. Also, it would be necessary to investigate levels of persistent organic pollutants (POPs) in beaver tissues. POPs are hydrophobic and lipophilic persistent compounds that may accumulate along the food chain and can cause severe metabolic disturbance, such as endocrinal disturbance (Jones and de Voogt 1999). The presence of POPs in remote areas such as the Arctic is a major environmental issue (Brault et al. 2013). Consequently, we recommend future research and regular monitoring to identify the source of contaminants in the ecosystem and possible mitigation measures, and to ensure that contamination levels are within a safe range.

Acknowledgments Animal captures were conducted by a specialized team from the Polish Hunting Association. This study was funded by the Department of Pharmacology and Toxicology, Faculty of Veterinary Medicine, University of Warmia and Mazury, Olsztyn, Poland.

Open Access This article is distributed under the terms of the Creative Commons Attribution License which permits any use, distribution, and reproduction in any medium, provided the original author(s) and the source are credited.

\section{References}

Ansara-Ross TM, Ross MJ, Wepener V (2013) The use of feathers in monitoring bioaccumulation of metals and metalloids in the South African endangered African grass-owl (Tyto capensis). Ecotoxicology 22:1072-1083
Bilandžić N et al (2010) Concentrations of trace elements in tissues of red fox (Vulpes vulpes) and stone marten (Martes foina) from suburban and rural areas in Croatia. Bull Environ Contam Toxicol 85:486491

Bjerregaard P, Andersen O (2011) Ecotoxicology of metals-sources, transport, and effects in the ecosystem. In: Nordberg G, Fowler B, Nordberg M, Friberg L (eds) Handbook on the toxicology of metals, 3rd edn. Academic, London, pp 251-280

Brault EK, Goebel ME, Geisz HN, Canuel EA, Dickhut RM (2013) Interannual variation of persistent organic pollutants (POPS) in an Antarctic top predator Arctocephalus gazella. Environ Sci Technol 47:12744-12752

Brekken A, Steinnes E (2004) Seasonal concentrations of cadmium and zinc in native pasture plants: consequences for grazing animals. Sci Total Environ 326:181-195

European Commission (2006) Commission Regulation (EC) no 1881/ 2006 setting maximum levels of certain contaminations in foodstuff (L3 364/5)

Fimreite N, Parker H, Rosell F, Hosen DA, Hovden A, Solheim A (2001) Cadmium, copper, and zinc in Eurasian beaver (Castor fiber) from Bo, Telemark, Norway. Bull Environ Contam Toxicol 67:503-509

Flis M (2013) Ecological, legal and economic aspects of evaluating the damages caused by wild animals. Environ Protect Nat Resour 24:53-58

Giżejewska A, Spodniewska A, Barski D (2014) Concentration of lead, cadmium, and mercury in tissues of European beaver (Castor fiber) from the north-eastern Poland. Bull Vet Inst Pulawy 58:77-80

Haarberg O, Rosell F (2006) Selective foraging on woody plant species by the Eurasian beaver (Castor fiber) in Telemark, Norway. J Zool 270:201-208

Hillis T, Parker G (1993) Age and proximity to local ore-smelters as determinations of tissue metal levels in beaver (Castor canadensis) of the Sudbury (Ontario) area. Environ Pollut 80:67-72

Jankowska B, Żmijewski T, Kwiatkowska A, Korzeniowski W (2005) The composition and properties of beaver (Castor fiber) meat. Eur J Wildl Res 51:283-286

Jerez S, Motas M, Benzal J, Diaz J, Vidal V, D’Amico V, Barbosa A (2013) Distribution of metals and trace elements in adult and juvenile penguins from the Antarctic Peninsula area. Environ Sci Pollut Res 20:3300-3331

Jones KC, de Voogt P (1999) Persistent organic pollutants (POPs): state of the science. Environ Pollut 100:209-221

Krojerová-Prokešová J, Barančeková M, Hamšíková L, Vorel A (2010) Feeding habits of reintroduced Eurasian beaver: spatial and seasonal variation in the use of food resources. J Zool 281:183-193

Łuczyńska J, Tońska E, Łuczyński MJ (2009) Essential mineral components in the muscles of six freshwater fish from the Mazurian Great Lakes (northeastern Poland). Arch Pol Fish 17:171-178

Mason CF, Stephenson A (2001) Metals in tissues of European otters (Lutra lutra) from Denmark, Great Britain and Ireland. Chemosphere 44:351-353

Nasreddine L, Parent-massin D (2002) Food contamination by metals and pesticides in the European Union. Should we worry? Toxicol Lett 127:29-41

Nordberg G, Gerhardsson L, Broberg K, Mumtaz M, Ruiz P, Fowler B (2011a) Interactions in metal toxicology. In: Nordberg G, Fowler B, Nordberg M, Friberg L (eds) Handbook on the toxicology of metals, 3rd edn. Academic, London, pp 117-145

Nordberg G, Nogawa K, Nordberg M, Friberg L (2011b) Cadmium. In: Nordberg G, Fowler B, Nordberg M, Friberg L (eds) Handbook on the toxicology of metals, 3rd edn. Academic, London, pp 446-486

O'Brien D, Kaneene J, Poppenga R (1993) The use of mammals as sentinels for human exposure to toxic contaminants in the environment. Environ Health Perspect 99:351-368

Parker GH, Hamr J (2001) Metal levels in body tissues, forage and fecal pellets of elk (Cervus elaphus) living near the ore smelters at Sudbury, Ontario. Environ Pollut 113:347-355 
Petkovšek S, Kopušar N, Kryštufek B (2014) Small mammals as biomonitors of metal pollution: a case study in Slovenia. Environ Monit Assess 186:4261-4274

Polish Minister of the Environment (2011) Regulation on animal species under protection. Law Gazette No 237, item 1419

R Core Team (2013) R: a language and environment for statistical computing. Foundation for Statistical Computing, Vienna, Austria. URL http://www.R-project.org/

Rajaganapathy V, Xavier F, Sreekumar D, Mandal P (2011) Heavy metal contamination in soil, water, and fodder and their presence in livestock and products: a review. J Environ Sci Technol 4:234-249

Rosell F, Zedrosser A, Parker H (2010) Correlates of body measurements and age in Eurasian beaver from Norway. Eur J Wildl Res 56:43-48
Schulte BA, Müller-Schwarze D, Sun L (1995) Using anal gland secretion to determine sex in beaver. The Journal of wildlife management: $614-618$

Szkoda J, Durkalec M, Kołacz R, Opaliński S, Żmudzki J (2012) Content of cadmium, lead and mercury in the tissues of game animals. Vet Med 68:689-692

Whiteside P, Milner B (1984) Pye Unicam atomic absorption data book. Pye Unicam Ltd., Cambridge

Wren C (1984) Distribution of metals in tissues of beaver, raccoon and otter from Ontario, Canada. Sci Total Environ 34:177-184

Zalewski K, Falandysz J, Jadacka M, Martysiak-Żurowska D, Nitkiewicz B, Giżejewski Z (2012) Concentrations of heavy metals and PCBs in the tissues of European beavers (Castor fiber) captured in northeastern Poland. Eur J Wildl Res 58:655-660 